\title{
Urban resilience: an instrument to decode the post- socialist socio-economic and spatial transformations of cities from Central and Eastern Europe
}

\author{
Alexandra SANDU*, Alexandru BĂNICĂ ${ }^{* *}$, Ionel MUNTELE ${ }^{* * *}$
}

\begin{abstract}
A widely used concept, urban resilience, cannot remain a metaphor or just a theoretical view on the ability of cities to overcome perturbations, but it also needs to be operationalized and to become a useful tool in deciphering the complex and very dynamic urban realities. The present study investigates the resilience of 76 selected cities from Central and Eastern Europe from the point of view of socioeconomic indicators (socio-economic resilience), as well as from the point of view of morphological and functional indicators (spatial resilience). The methodology is quantitative, based on statistical analyses which link the socio-economic evolution of the cities to the spatial one in order to observe the disturbances. The results show us a territory of Central and Eastern Europe at several speeds. The differences exist because of a differentiated structural change that took place after the collapse of communism (depending on the proximity or distance to the border with Western Europe), but also linked to the existence of different socio-economic resources (Western cities vs Eastern cities of Poland, Romania, Bulgaria), based on their different history and the trajectory taken since the fall of communism.
\end{abstract}

Keywords: urban resilience, urban functions, adaptive cycle, post-socialist city, Central and Eastern Europe

\footnotetext{
*Alexandra SANDU is Research Assistant at the Wales Institute of Social and Economic Research, Data and Methods - Cardiff University, UK; e-mail: SanduA@cardiff.ac.uk.

** Alexandru BĂNICĂ is Lecturer at the Faculty of Geography and Geology, Alexandru Ioan Cuza University of Iași, Romania and Researcher at Romanian Academy - Iași Branch, Geography Collective; e-mail: alexandrubanica@yahoo.com.

*** Ionel MUNTELE is Professor at the Faculty of Geography and Geology, Alexandru Ioan Cuza University of Iași, Romania and Researcher at Romanian Academy - Iași Branch, Geography Collective; e-mail: imuntele@yahoo.fr.
} 


\section{Introduction}

The concept of resilience questions a system when confronted with internal or external disturbances. Applied to a city from an evolutionary perspective, resilience can be defined as the capacity of the urban organism to absorb a disturbance or a shock and continue to develop coherently through structural and functional adaptation and/or transformation (Brand and Jax, 2007; Masnavi et al., 2019). Consequently, it is certainly a fitting methodological angle of analysis for the socioeconomic and spatial transformations of cities from Central and Eastern Europe, as its urban system was submitted to a succession of political, socio-economic and spatial shocks throughout its evolution (e.g. the rise and fall of the communist regime).

As such, this exploratory empirical study focuses on 76 cities from Central and Eastern Europe in a bid to understand certain patterns of urban resilience capacity in this part of Europe. Thus, two research questions are implied:

- Do cities with a better relative resilience capacity also perform better in what concerns the spatial urban development?

- Does a better relative resilience capacity imply an increased built-up area growth rate, or does the opposite apply?

It should be mentioned that a (very) high resilience capacity means that a city is able to adapt and to sustain positive dynamics concerning both socio-economics and spatial components. Conversely, a (very) low resilience capacity means that a city shows difficulties in adapting to changes and in maintaining positive urban dynamics. Consequently, performing better in what concerns the spatial urban development refers to assuring a balance within the different land-use types and also controlling the urban sprawl phenomena.

\section{Theoretical background}

Cities are highly dynamic and complex systems that comprise interacting physical, socio-economic and environmental subsystems. Meanwhile, they are also part of "systems of cities", therefore the multiscale and cross-scale interactions are also important at regional, national, continental or global level (Ernstson et al., 2010).

Urban resilience is currently a prominent topic in a world of increasing uncertainties, perturbations and challenges. Resilience is not just going back to equilibrium after a disruptive event, but also the capacity of complex systems, such as cities, to change, adapt and transform in response to stresses and shocks (Carpenter et al., 2001).

The numerous existing urban resilience perspectives and principles can be framed in three categories: 1) resilience of urban structures and provided services; 2) urban metabolism, efficiency and sustainability of resources management and 3) social aspects embedded within urban dynamics (Chelleri, 2015). All these approaches need 
the integration of the urban morphology, infrastructure, economic, social and environmental components which are all connected by various physical and social dispersion processes (Holling and Goldberg, 1971; Marcus and Colding, 2014).

The co-evolution of this mosaic of elements of urban systems is symbolised by the concept of adaptive renewal cycles (Holling, 1986). It represents a succession of four phases: growth (exploitation), conservation (steady-state), collapse (release) and reorganization (reorientation). Resilience differs in each of these phases as it is higher in the growth and renewal phase and lower during the conservation and release phases (Chelleri, 2012). The needs for differentiated measures in urban management and planning are different for each of these phases of adaptation. In this regard, the urban transition has many of the characteristics of ecological succession (where the adaptive cycles model was first applied) as "the same non-linear, discontinuous structural proprieties noted in ecological systems apply to urban systems" (Marcus and Colding, 2014, p. 3).

Meanwhile, the resilience of cities depends on the spatial scales. In this regard, a comprehensive definition of urban resilience refers to "the ability of an urban system and all its constituent socio-ecological and socio-technical networks across temporal and spatial scales to maintain or rapidly return to desired functions in the face of a disturbance, to adapt to change and to quickly transform systems that limit current or future adaptive capacity" (Meerow and Newell, 2016).

In fact, the scales of urban resilience divide the existing approaches into two categories: 1) local-scale urban resilience approaches, that deal with punctual and rather specific shocks that affect urban communities (such as natural disasters, changes of regime/administration, transformative planning decisions etc.), regionalscale urban studies, which refer more to the response and adaptation to national or international shocks (Rogov and Rozenblat, 2018). There are also approaches that combine the two scales and some which refer to general resilience capacity not necessarily and directly linked to a certain shock, but to stressors and gradual transformation (transition) (Bănică and Muntele, 2017).

This perspective is integrated within the evolutionary perspective of resilience which envisages urban dynamics as a continuous process of adjustment, but also including radical ruptures that were felt differently by different cities. Therefore, instead of trying to actually calculate resilience in absolute terms, a relative resilience ${ }^{1}$ could be more appropriate i.e. to compare different units that evolved in more or less the same conditions in terms of their performance and capacity of adapting and transforming in a positive way.

\footnotetext{
${ }^{1}$ The relative resilience is a concept used especially in ecology for a systemic perspective as a comparison between interrelated elements - some being more resilient than others (Allen, 2005). For e.g. Angeler et al., (2013) assess the relative resilience of different states (regimes) of ecological systems, while Maynard et al., (2015) test the spatial differentiation of resilience between different coral reefs.
} 


\section{Resilience of Central and Eastern European cities}

Former communist Central and Eastern European countries represent a good subject of urban resilience, as they were affected by numerous changes and challenges (political, social, economic, institutional, ecological etc.) in the last 30 years. During this entire period, the slow and gradual processes of urbanisation, suburbanisation, deurbanisation and reurbanisation alternated with moments of turbulent restructuring (Berki, 2014). From the resilience viewpoint, they acted as shocks (political turbulences, the economic crisis) or as stressors (the socialeconomic and institutional transition, the integration within EU etc.) with various impact on cities: expansion of cities by urban sprawl, but also urban shrinkage related to deindustrialization, demographic decline, emerging forms of social and economic inequalities etc. (Bănică et al., 2017). Meanwhile, their development trends are, to a high degree, dissimilar from the other cities from the EU due to a combination of multiple causes, from historical context and planning tradition to social-economic patterns (Stanilov, 2007; Cortinovis et al., 2019).

One can clearly delineate the decade of the 1990s, with intensive but deregulated transformations of urban areas in a weak political context, from the last two decades when changes were even more accelerated, despite the more solid political and regulatory framework (Garcia-Ayllon, 2018). The transition processes of these countries, from a highly centralized system to a market economy, was analysed by many scholars, all highlighting multiple institutional, social and urban transformations that created a mosaic of various urban experiences (Tsenkova and Budic, 2006; Sykora and Bouzarovski, 2012). The concept of post-socialist urban mosaic can be understood from different, but complementary, perspectives: reconfiguration of built areas, land use patterns, new social-economic conditions and socio-spatial differentiations (Sykora and Bouzarovski, 2012). Drobniak (2017) introduces the term of hybridization, that is intrinsically linked to resilience and includes mixed social and economic dynamics and mosaicked urban morphologies. The idea is derived from a previous paper (Tsenkova and Budic, 2006), which focuses on economic, societal, institutional and spatial dynamics emphasizing the implications for urban planning and policy in post-socialist Central and Eastern Europe. In fact, the term "urban mosaic" describes the complexity, diversity and uniqueness of the processes and spatial outcomes of the above-mentioned cities.

All these changing characteristics of the post-socialist city can be reinterpreted by the filter of social resilience (Bouzarovski et al., 2011), economic resilience (Drobniak, 2014), physical /morphologic resilience (Rufat, 2012), environmental resilience (Badiu et al., 2019) or in integrated approaches that systemically combine the outcomes of all these approaches.

The types of resilience in relation to urban systems based on a multidimensional index that integrates morphological, social-demographic and functional transformation of post-communist countries were also assessed before 
(Bănică and Muntele, 2017), but there is a need for more dynamic, time-series data analysis that could better highlight, in a more detailed manner, the moments and the stages of the urban transition and adaptation.

\section{Data and methodology}

Our study focused on 76 selected cities from Central and Eastern Europe, for which we analysed the relative resilience capacity through the socio-economic and spatial dynamics. The cities chosen are representative of the CEE regarding both demographic and functional diversity. However, it should be mentioned that the choice was also limited by data availability for the common indicators that were used in our study. Thus, the analysis of the urban relative resilience capacity of the selected cities will be made by observing the recurrence and/or the predominance, in space and time, of certain land use types which can show an adaptive capacity as well as an evolution of a city in terms of physical resources. The focus will be on the socio-economic stability of cities, because it plays a role in the urban evolutionary trajectory, being an important factor in the urban adaptation, transformation or stagnation. Therefore, 12 indicators were selected, of which six focus on the socioeconomic dynamic and six focus on the urban spatial dynamics, either functional or morphological (Table 1). As it can be observed, the main sources for the database were Eurostat and National Census for the socio-economic indicators, while for the spatial ones, the GMES Urban Atlas was used, a database developed by European Program Copernicus which provides high-resolution land use dynamics of urban areas (with more than 100000 inhabitants as defined by the Urban Audit) for the period between 2006 -2012. This period overlaps the beginning and the end of the economic crisis, which can be considered, without a doubt, a shock in the evolution of the cities chosen for the analysis of their resilience capacity. The choice of indicators was restricted by the data availability at city level on this specific timeframe and for all cities taken into account.

Table 1. List of indicators used in the study

\begin{tabular}{|c|c|c|c|c|}
\hline Indicators & Period & Source(s) & $\begin{array}{l}\text { Resilience } \\
\text { type }\end{array}$ & $\begin{array}{l}\text { Theoretical } \\
\text { Sources } \\
\text { /References }\end{array}$ \\
\hline $\begin{array}{l}\text { Population growth rate } \\
\qquad(\%)\end{array}$ & $\begin{array}{l}1990- \\
2015\end{array}$ & $\begin{array}{l}\text { Eurostat, } \\
\text { National } \\
\text { Census by } \\
\text { Country }\end{array}$ & $\begin{array}{l}\text { Socio- } \\
\text { economic }\end{array}$ & $\begin{array}{c}\text { (Bănică and Muntele, } \\
\text { 2017; Rizzi et al., } \\
\text { 2018; da Silva et al., } \\
\text { 2019) }\end{array}$ \\
\hline
\end{tabular}




\begin{tabular}{|c|c|c|c|c|}
\hline $\begin{array}{l}\text { Birth rate } \\
\qquad \%)\end{array}$ & $\begin{array}{l}2006 \\
2012\end{array}$ & Eurostat & $\begin{array}{l}\text { Socio- } \\
\text { economic }\end{array}$ & $\begin{array}{c}\text { (Bănică and Muntele, } \\
\text { 2017; Konecka- } \\
\text { Szydłowska, 2018) }\end{array}$ \\
\hline $\begin{array}{l}\text { Share of the elderly } \\
\text { population } \\
(\%)\end{array}$ & $\begin{array}{l}2006 \\
2012\end{array}$ & Eurostat & $\begin{array}{l}\text { Socio- } \\
\text { economic }\end{array}$ & $\begin{array}{l}\text { (Cutter, 2008; Bănică } \\
\text { and Muntele, 2017) }\end{array}$ \\
\hline $\begin{array}{l}\text { Infant mortality rate } \\
\text { (per } 1000 \text { live births) }\end{array}$ & $\begin{array}{l}2006 \\
2012\end{array}$ & Eurostat & $\begin{array}{l}\text { Socio- } \\
\text { economic }\end{array}$ & $\begin{array}{l}\text { (Bănică and Muntele, } \\
\text { 2017; da Silva et al., } \\
\text { 2019) }\end{array}$ \\
\hline $\begin{array}{l}\text { Share of students in } \\
\text { tertiary education in } \\
\text { the total population } \\
\text { (per } 1,000 \text { persons) }\end{array}$ & $\begin{array}{l}2006 ; \\
2012\end{array}$ & Eurostat & $\begin{array}{l}\text { Socio- } \\
\text { economic }\end{array}$ & $\begin{array}{c}\text { (Reggiani et al., 2016; } \\
\text { Bănică and Muntele, } \\
\text { 2017; Hudec et al., } \\
\text { 2018) }\end{array}$ \\
\hline $\begin{array}{l}\text { GDP per person } \\
(€)\end{array}$ & $\begin{array}{l}2006 ; \\
2012\end{array}$ & Eurostat & $\begin{array}{l}\text { Socio- } \\
\text { economic }\end{array}$ & $\begin{array}{l}\text { (Briguglio et al., 2009; } \\
\text { Martin, 2012; Sharifi } \\
\text { and Yamagata, 2014) }\end{array}$ \\
\hline $\begin{array}{l}\text { Share of built-up area } \\
(\%)\end{array}$ & $\begin{array}{l}2006 ; \\
2012\end{array}$ & $\begin{array}{l}\text { GMES Urban } \\
\text { Atlas } \\
2006 \& 2012\end{array}$ & Spatial & $\begin{array}{c}\text { (Bănică and Muntele, } \\
\text { 2017; Rizzi et al., } \\
\text { 2018; da Silva et al., } \\
\text { 2019) }\end{array}$ \\
\hline $\begin{array}{c}\text { Share of Green urban } \\
\text { Areas } \\
(\%)\end{array}$ & $\begin{array}{l}2006 \\
2012\end{array}$ & $\begin{array}{l}\text { GMES Urban } \\
\text { Atlas } \\
2006 \& 2012\end{array}$ & Spatial & $\begin{array}{l}\text { (Sharifi and Yamagata, } \\
\text { 2016; Bănică and } \\
\text { Muntele, 2017; } \\
\text { Carvalho et al., 2017) }\end{array}$ \\
\hline $\begin{array}{c}\text { Share of construction } \\
\text { sites }(\%)\end{array}$ & $\begin{array}{l}2006 ; \\
2012\end{array}$ & $\begin{array}{l}\text { GMES Urban } \\
\text { Atlas } \\
2006 \& 2012\end{array}$ & Spatial & $\begin{array}{l}\text { (Carvalho et al., 2017; } \\
\text { Datola et al., 2019) }\end{array}$ \\
\hline $\begin{array}{c}\text { Share of residential } \\
\text { areas } \\
(\%)\end{array}$ & $\begin{array}{l}2006 ; \\
2012\end{array}$ & $\begin{array}{l}\text { GMES Urban } \\
\text { Atlas } \\
2006 \& 2012\end{array}$ & Spatial & $\begin{array}{c}\text { (Mayunga 2007; } \\
\text { Carvalho et al., 2017; } \\
\text { da Silva et al., 2019) }\end{array}$ \\
\hline $\begin{array}{c}\text { Share of industrial } \\
\text { and/or commercial } \\
\text { areas } \\
(\%)\end{array}$ & $\begin{array}{l}2006 \\
2012\end{array}$ & $\begin{array}{l}\text { GMES Urban } \\
\text { Atlas } \\
2006 \& 2012\end{array}$ & Spatial & $\begin{array}{c}\text { (Mayunga, 2007; } \\
\text { Cutter, 2008; Carvalho } \\
\text { et al., 2017) }\end{array}$ \\
\hline $\begin{array}{l}\text { Share of land without } \\
\text { use } \\
(\%)\end{array}$ & $\begin{array}{l}2006 ; \\
2012\end{array}$ & $\begin{array}{l}\text { GMES Urban } \\
\text { Atlas } \\
2006 \& 2012\end{array}$ & Spatial & $\begin{array}{c}\text { (Carvalho et al., 2017; } \\
\text { Datola et al., 2019) }\end{array}$ \\
\hline
\end{tabular}

Source: Authors' representation

As far as methodology is concerned, one fact should be stated, namely that the methodology is based on a dual approach. On the one hand, it focuses on the socio- 
economic resilience, which was derived by calculating a relative resilience capacity through the aggregation of the sum of cities ranks in each of the socio-economic indicators, which grounds a classification of the studied cities in five classes obtained through the Jenks natural breaks classification method (very high resilience, high resilience, average resilience, low resilience and very low resilience). The resulted categories of relative resilience capacity were then used to derive an adaptive cycle model for CEE cities which highlights the reflection of political and socio-economic shocks on the demographic trends for each of them for the period between 1990 and 2015. Namely, the adaptive cycle model is derived by analysing the data and identifying the shocks in the demographic evolution (a sharp increase or decrease of the population) for each of the five classes obtained through the methodology detailed above. Finally, a map showing the current phase of evolution within the adaptive cycle for each city was derived for a better synthesis of the results.

On the other hand, the approach combines the socio-economic aspects with the spatial ones. More precisely, starting once again from the five classes derived earlier, the particularities of land use dynamics that characterise the 76 cities were observed in order to see what a better spatial resilience capacity consists of.

Each indicator chosen for this study is therefore relevant, either as a mark of attractiveness, adaptability, connectivity, diversity, efficiency and redundancy, resulting in a good capacity for resilience, or as a mark of fragmentation, ineffectiveness, insufficiency or discordance, inducing vulnerability and therefore a poor capacity for resilience (Drobniak, 2014), as we detail in what follows.

As far as socio-economic indicators are concerned, the growth rate of the population is a proxy for the availability of human capital, a very important resource in building the resilience capacity (Mayunga, 2007), as well as a mark of the attractiveness of the urban area. The percentage of the elderly population shows the existence of a vulnerability within a city (Cutter, 2008; Bănică and Muntele, 2017), while the birth rate is regarded as a proxy for the vitality of the population (KoneckaSzydłowska, 2018), especially in a context of a significant process of ageing in the population of countries from Central and Eastern Europe. The GDP is considered a proxy for a strong, efficient and competitive economic development (Mayunga, 2007; Briguglio et al., 2009; Martin, 2012; da Silva et al., 2019), while a high infant mortality rate is regarded as a proxy for deficiencies and shortages within the socioeconomic development (Konecka-Szydłowska, 2018; da Silva et al., 2019). The share of the population that attends higher education testifies to the future human capital available for the development of the city (Mayunga, 2007).

Moving on to spatial indicators, the percentage of the built-up area within the administrative study zone (Urban Morphologic Zone - UMZ) is a proxy for the anthropic pressure by extending the artificialized areas, which thus reduces the capacity of resilience (Rizzi et al., 2018; da Silva et al., 2019), but can also imply a socio-economic attractiveness, along with an increasing share of construction sites (Carvalho et al., 2017; Datola et al., 2019). The percentage of green urban areas is a 
proxy for the provision of a natural capital (Mayunga, 2007; da Silva et al., 2019), testifying better access to green infrastructure within increasingly soil sealing areas.

Both the share of residential areas and industrial and/or commercial areas are regarded as proxies for the provision of the physical capital, namely the spatial resources needed for building the resilience capacity (Mayunga, 2007), while the percentage of land without use is a proxy for fragmentation and ineffectiveness in regard to the urban soil consumption (Datola et al., 2019) and therefore vulnerabilities in what concerns the land use planning policies. These areas could also be considered spare capacities for the system, i.e. reserves that can be used for future developments and, in this sense, they could contribute to increasing resilience capacity.

In fact, a well-balanced land use planning is undoubtedly a key factor in having a (very) high resilience capacity within an urban area. Nevertheless, it can only be attained if the socio-economic factors behind it are also harmonious and efficiently developing and therefore capable of sustaining a balanced evolution/progress.

Finally, it should be noted that the urban resilience capacity we calculated, is, as the name itself implies, relative in regard to the cities that were analysed in this study. As the specialty literature (Resilience Alliance, 2007) shows, it is a complex, but also a relative feature that cannot be defined in absolute terms and it is often used in comparative analyses, like the Resilience Capacity Index (Foster, 2011), Resilience City Index (ARUP 2014) or Urban Resilience Index (UN-HABITAT 2012) $)^{2}$ etc.

\section{Results and discussions}

\subsection{Relative resilience capacity of cities from Central and Eastern Europe}

In a context where urban morphological transformation is dependent on political and socio-economic dynamics, the analysis of urban resilience should be considered both from the perspective of physical (spatial) resilience and the socioeconomic one, in order to link the space - urban fabric - to the factors that transform it. The cities of Central and Eastern Europe have been submitted to numerous pressures and even shocks during their morphological, functional and socioeconomic crystallization. Among these shocks, the collapse of communism, the transition to a market economy, the European Union integration process and the economic crisis are undoubtedly the major events, which tested their ability to readjust and continue to evolve, and therefore their urban resilience capacity. Therefore, this opens the possibility of analysing both the resilience capacity resulting from the transformations undergone after the fall of communism and the resilience performance in terms of outcome in rapport to the economic crisis that

${ }^{2}$ UN-HABITAT (2012), Urban Resilience Indexing Programme 
burst in 2008. It should be noted, however, that the shocks induced by the economic crisis will be the main focus, as most of the indicators used overlap it. The shocks induced by the fall of the communist regime will be directly analysed through the adaptive cycle model for the demographic evolution and indirectly for the relative resilience capacity, through its more or less visible spatial or socio-economic consequences for the period $2006-2012$.

The relative resilience capacity (Figure 1) shows the outline of a decreasing West - East gradient at both regional level and national level, the spatial distribution of classes certifying also the centre - periphery model that characterises Romania, Bulgaria and Hungary, where the capitals and 1-2 major cities (Cluj-Napoca, Plovdiv) tend to concentrate the socio-economic development. It should also be mentioned that the better relative resilience capacity of the South-West part of Bulgaria could be an effect of the influence of the proximity to Greece or Turkey, as well as one directly linked to the presence of the capital -Sofia.

Moreover, it outlines the presence of some major development axes that tend to concentrate and dictate the socio-economic evolution of Central and Eastern Europe, due to both the historical heritage like the old axis of Habsburg influence from Vienna to the Eastern part of the Czech Republic (Moravia) or to the Western Slovakia and the proximity to Western Europe like the Gdansk-Poznan-Wroclaw development axis in Western Poland.

Analysing the relative resilience capacity at the national level (Figure 2), one could note the existence of much contrasted regional dynamics with large inter-urban differences. Hence, there are important contrasts in Romania, Bulgaria and Hungary, but also in Poland and the Czech Republic. Nevertheless, at a general level, Bulgaria has the highest difference in values, showing therefore important socio-economic development gaps. Neither Romania nor Hungary is doing much better, the differences in values being also high, the consequence of the important socioeconomic disparities that exist between the countries in the Eastern and Western part, but also between the capital and the rest of the cities. In fact, the hot-spots of cities with a (very) low resilience capacity of these two countries question the management of the socio-economic policies. Poland also registers high differences, but it should be mentioned that unlike the other 3 countries previously presented, most of the cities have a good relative resilience capacity, as shown above by the map (Figure 1) with two exceptions - Jelenia Gora and Zielona Gora - cities that had indeed difficulties in managing well the transformations imposed by the liberal market economy. 


\section{Figure 1. Relative Resilience capacity of cities from Central and Eastern Europe}

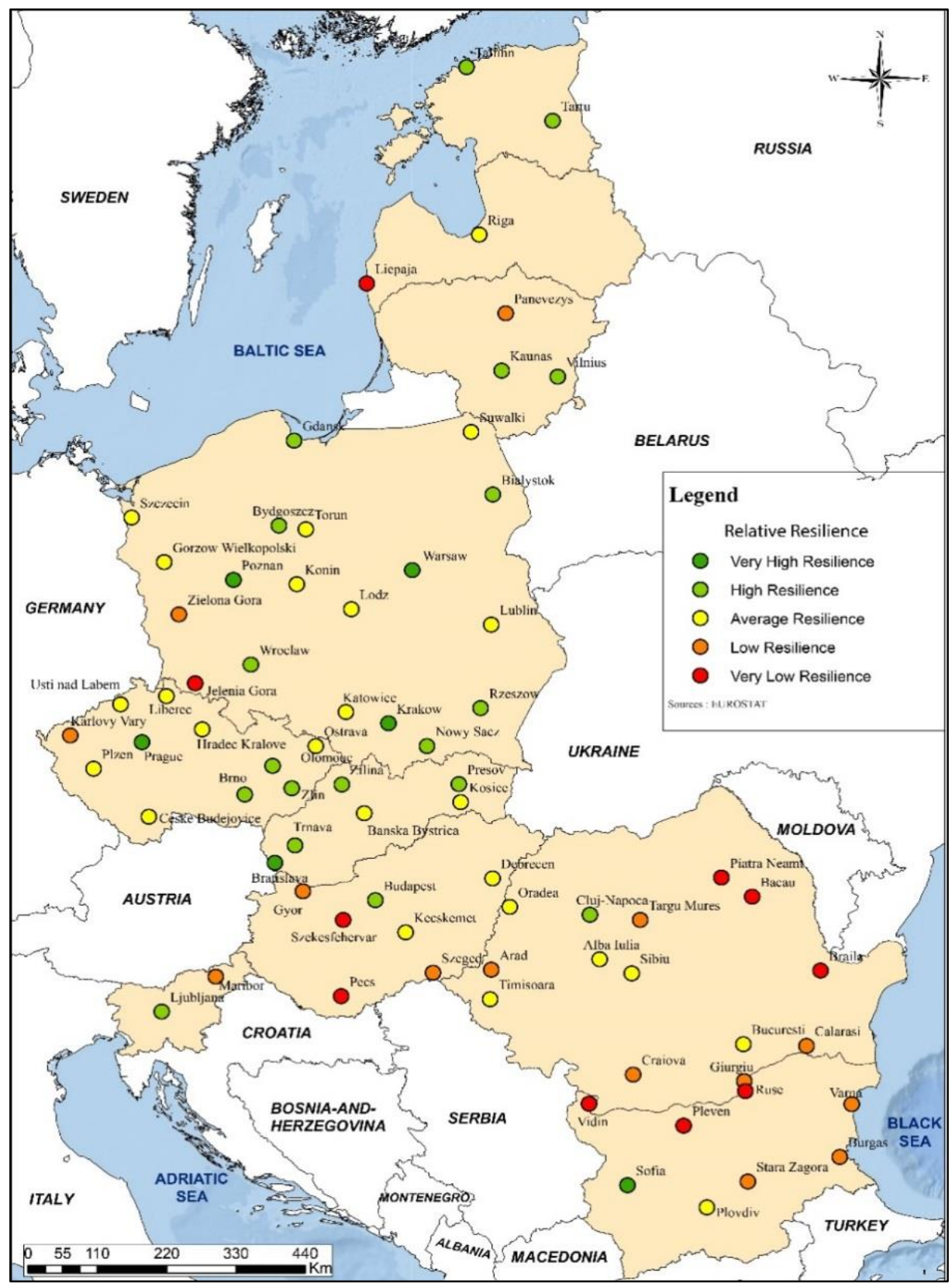

Source: Authors' representation 
Figure 2. Central values of relative resilience capacity at the national level

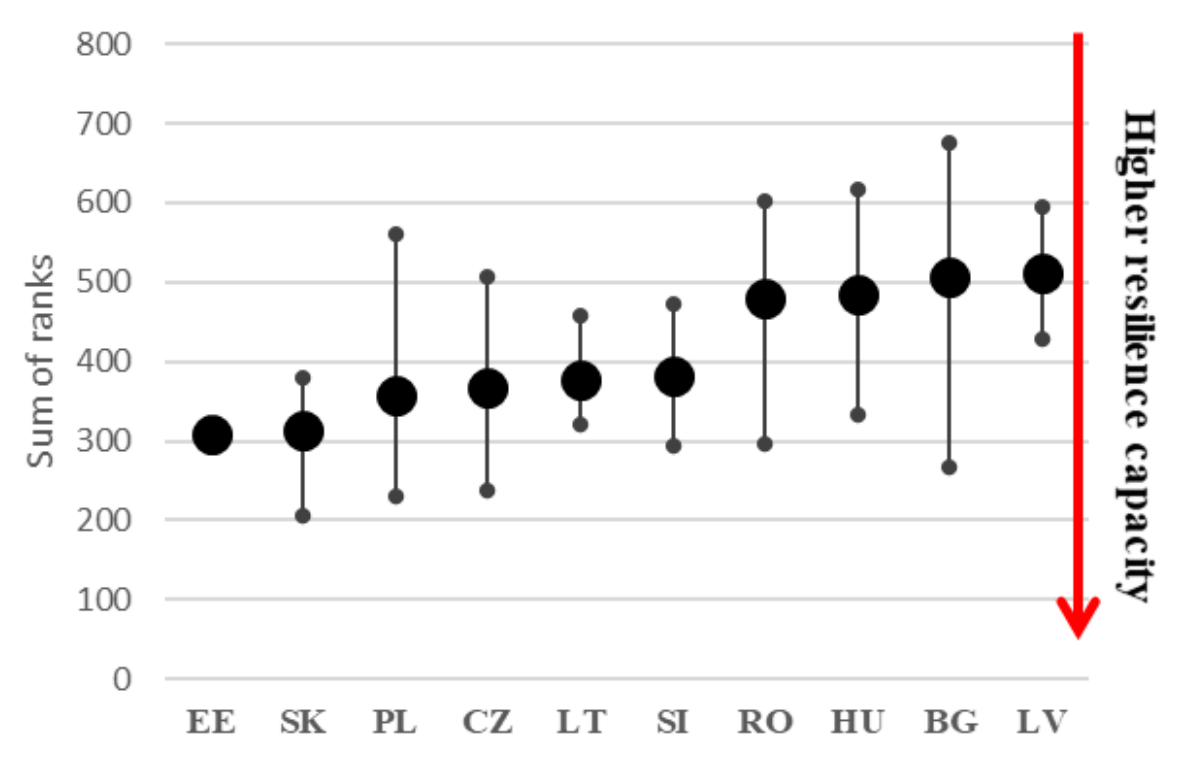

Source: Authors' representation

Analysing both the urban fabric dynamics and the demographic ones, it is easy to note that the population responds faster to changes and shocks than the urban fabric. The growth rate of the built-up area stays positive despite an increased negative growth rate of the population for the studied period (Figure 2). Hence, there is an obvious antagonism between urban sprawl and shrinking cities that characterise the main urban areas of Central and Eastern Europe, throughout the whole period after the fall of communism (Sandu, 2019), not only between 2006 - 2012. One could identify that two-thirds of the analysed cities have a negative growth rate of the population in contrast with a positive growth rate of the urban fabric, hence the very small value of the correlation coefficient (Figure 2). It is a category that includes capitals (Riga), but mostly groups cities that had difficulties in adapting to the demands of the liberal economic market and this could imply that they have a reduced capacity of adaptation and transformation, thus a small relative resilience capacity. The Latvian capital is a special case: the apparent decline is due to the massive departure of the Russian population, a phenomenon that is also present in Tallinn or Vilnius but on a smaller scale. 
Figure 3. The demographic vs the urban fabric dynamics: urban sprawl vs shrinking cities

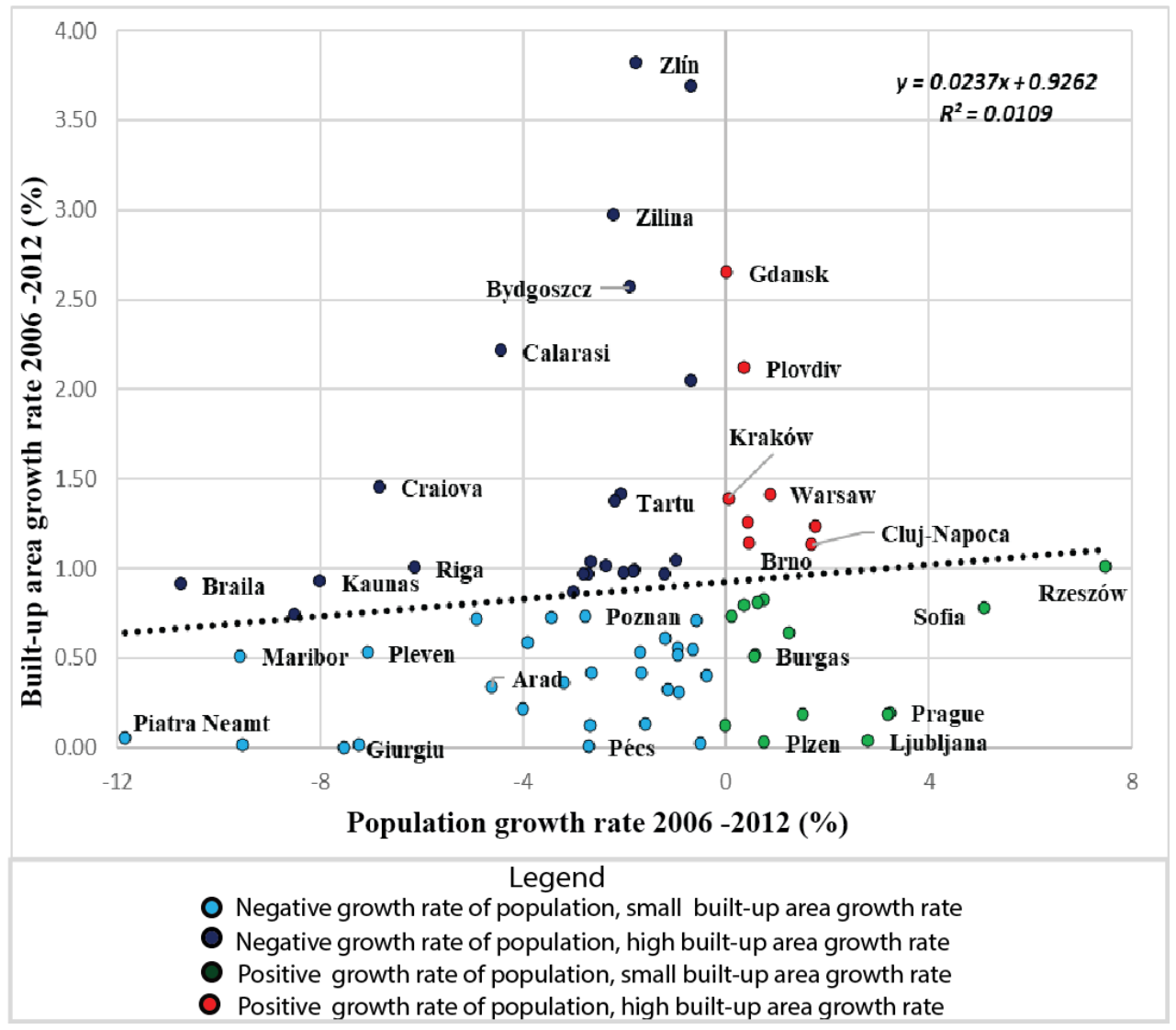

Source: Authors' representation

\subsection{Spatial dynamics vs. Relative Resilience in Central and Eastern Europe}

The relation between the relative resilience assessed above and the evolution of spatial patterns of the selected cities is far from being linear, as there are many different, sometimes contradictory factors that play a role in different CEE countries or even within the same country.

Moreover, Figure 4 highlights the idea that rapid increases in built-up areas do not necessarily mean a better relative resilience capacity, sometimes the result being quite the opposite (e.g. Székesfehérvár, Györ, Zielona Góra etc.), but a (very) low built-up area growth rate does not equate with a (very) high resilience capacity, either (e.g. Pecs, Bacău, Liepaja, Pleven, Vidin etc.). Nevertheless, there are cities 
that have both an above-average built-up area growth rate and a (very) high resilience capacity.

It is mostly the case of cities from Poland (Krakow, Warsaw, Poznan, Wroclaw etc.), the Czech Republic (Prague, Brno, Olomouc etc.) or Slovakia (Bratislava, Presov etc.), where the antithesis of urban planning versus urban sprawl comes into play, having a major role in the resilience capacity outcome. Central and Eastern Europe is still a territory confronted with an increased, but more importantly, uncontrolled urban sprawl that strongly decreases the urban resilience due to a negative anthropogenic stress. However, the above-mentioned countries and cities show that a well-controlled artificialization rate does not negatively affect the urban resilience capacity. Still, the correlation coefficient does not prove a strong connection between the artificialization growth rate and the resilience capacity of the studied cities, but specialty literature displays an emphasis on the benefits of a city that develops in a relatively compact manner and which has a well-balanced mix of the land-use types (Alberti and Marzluff, 2004; Sharifi, 2019). Therefore, the fragile equilibrium lies in the ability to find the key to efficiency and redundancy in what concerns the urban planning policies, which will consequently allow a coherent development. There is no surprise that cities from countries that have better managed the transition to the liberal market also seem to have found the solution to a coherent urban planning that allows spatial growth, but which also contains, as much as possible, negative side effects. Implicitly, it highlights the existence of a systemic urban development, yet one which is not without failure, at least when looking at the overall level, as there is still room for improvements because one could also identify a few cities that face important discordance, while others are just around the average level. However, containing the negative effects of the intensive urbanization phenomena has never been easy (Santos Cruz et al., 2013) and the results show it.

The stronger internal control of the transition to the liberal economy, as well as of the urban spatial (morphological and functional) transformations, is the key to cities showing higher relative resilience capacity. A well-balanced growth of both residential and industrial/commercial zones provide the physical capital for socioeconomic development, while the green urban areas provide the much-needed equilibrium between the natural capital and the built-up areas within increasingly artificialized cities. Therefore, it does not come as a surprise that most cities classified in classes one and two are from Poland, Czech Republic and Slovakia. 
Figure 4. Built-up area growth rate vs Relative Resilience in Central and Eastern Europe

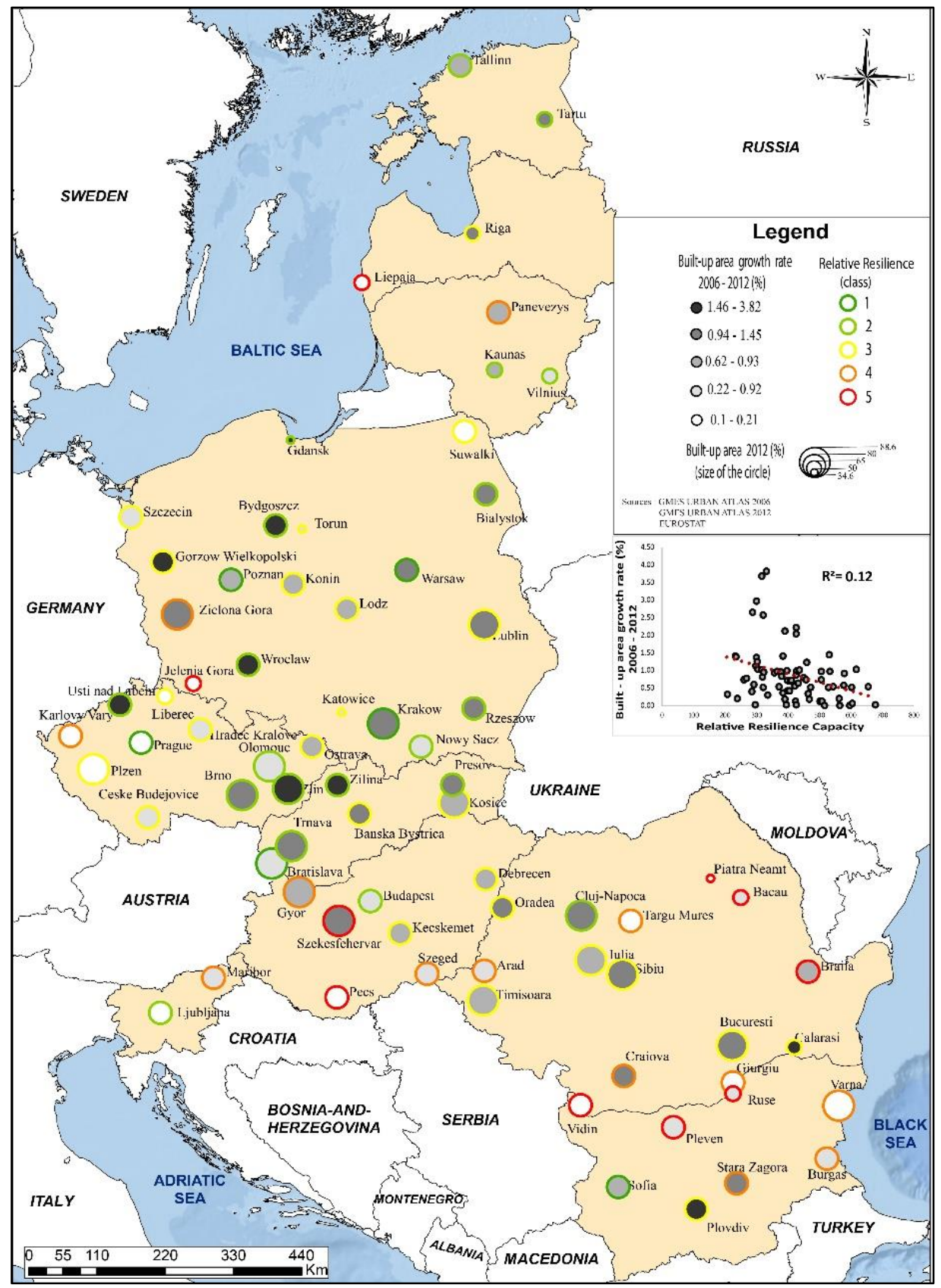

Source: Authors' representation 
Therefore, a higher relative resilience capacity derives from a good management of the transition to a market economy, a transition which results in a rather coherent and diverse functional dynamic, against the background of a flourishing economic development which is also supported by the demographic component, thus showing a good ability to adapt to a competitive economy, as well as a fairly good management of the available spatial resources. The green urban areas, along with the construction sites and the land without use, could be identified as the elements which tip the scale towards a high or low relative resilience capacity. A high growth rate for the first two shows adaptability and efficiency within increased soil-sealing urban areas and, last but not least, the attractiveness of the cities, while an increased growth rate of land without use marks the fragmentation within the urban fabric and the inefficiency of planning policies. Moreover, the increase in the surface of both the residential and industrial/commercial do favour a better relative resilience, but only if the increase is also accompanied by the growth of green urban areas which ensure the maintaining of a balanced urban land-use (Figure 5).

However, there are countries like Romania, Bulgaria and even Hungary that already came out from the communist regime with major internal development discrepancies and gaps, and the lack of continuity only deepened them. Hence, most of the cities not only lack the resources, but also the knowledge to better cope with a faulty inherited urban and socio-economic development. In contrast with the cities in Poland or the Czech Republic, the cities from Bulgaria and Romania focused on massively investing in the real estate sector, while ignoring the need and even the benefits of the regeneration of the brownfields and the creation of green urban areas in intensely artificialized urban areas. Consequently, they created even more vulnerabilities within an urban system that was already at a loss. 
Figure 5. Land-use dynamics in Central and Eastern Europe (central values)
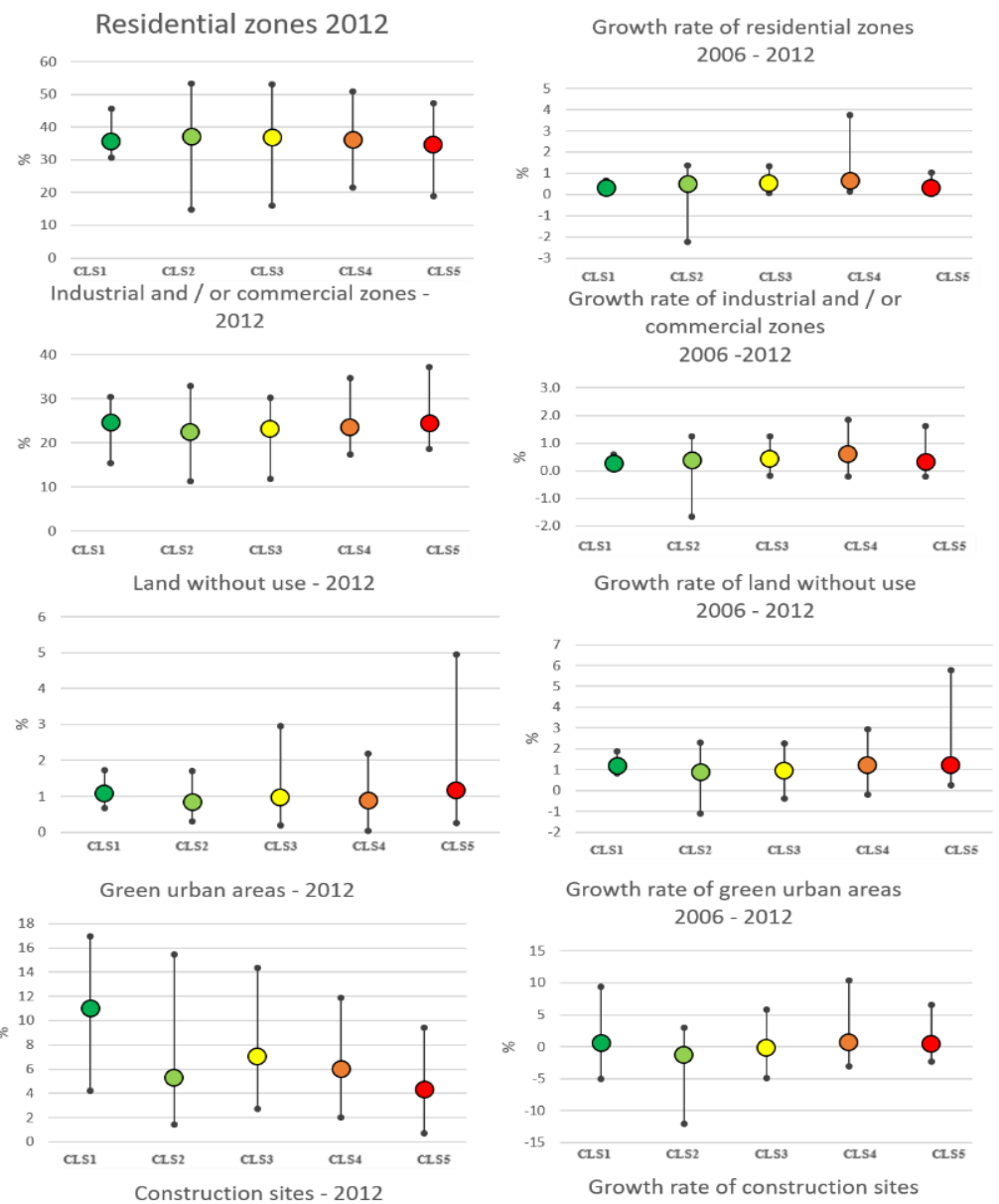

Growth rate of green urban areas $2006-2012$
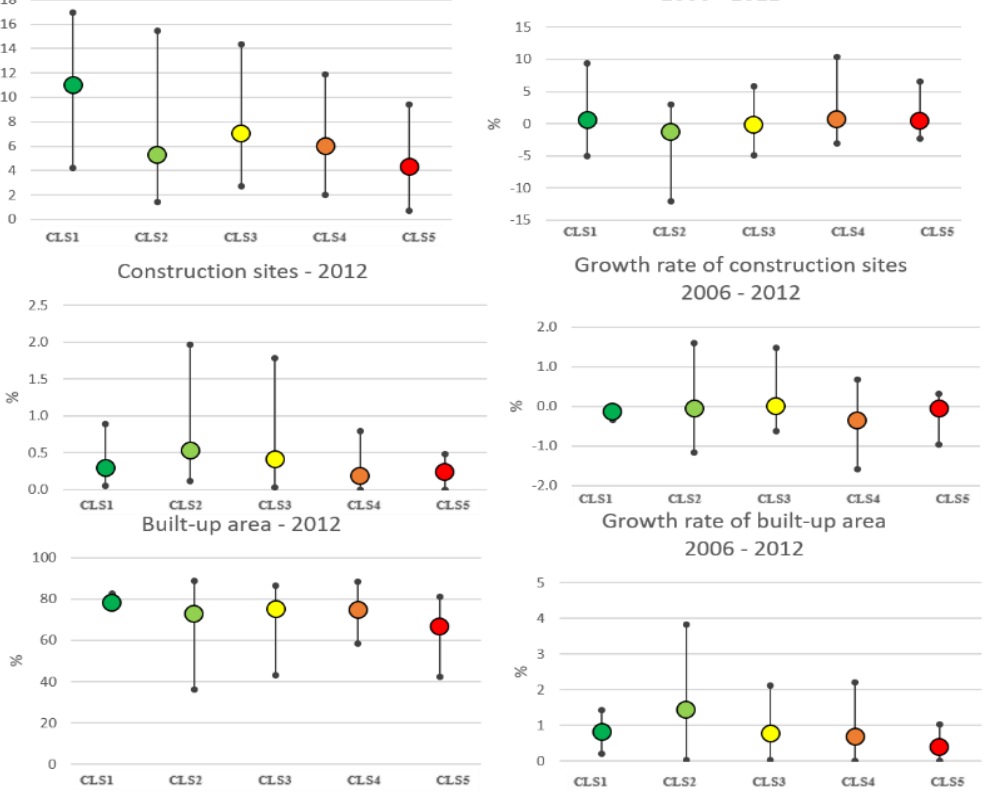

Source: Authors' representation 


\subsection{Demographic dynamics vs Relative Resilience in Central and Eastern Europe}

In an analysis of the demographic dynamics of the selected cities, one could note a higher correlation between the growth rate of population and the relative resilience capacity, but this is no surprise, as the population dynamic is one of the main indicators of the vitality of an urban area.

Most of the cities that show a better resilience capacity are those that managed to uphold a positive growth rate of the population (Krakow, Sofia, Prague, Warsaw, Gdansk etc.) in a territory strongly affected by the shrinking cities phenomenon. Nevertheless, there are some cities (e.g. Varna, Gyor, Zielona Gora etc.) which, despite having a positive growth rate, show a low relative resilience capacity, emphasising once again the idea that for an urban system to be resilient, all of its elements need to be synchronized, and if even one of them fails, the whole system may and will eventually fail, if the feedback received is not followed by local targeted solutions.

Analysing the adaptive cycle (Figure 7) derived by identifying the shocks for each of the five classes of relative resilience, one could note that four classes entered a phase of release in 1992, shortly after the fall of communism, one of the main shocks for the cities from Central and Eastern Europe. This phase is followed, for classes one and two, by a phase of reorganisation started in 2000 (class two), 2001 (class one). Finally, there is the phase of exploitation started in 2011 for the classes with the higher relative resilience (classes one and two). It should be mentioned that in what concerns class one, there is a different cycle identified for two major cities from Poland (Warsaw and Krakow), which seem to have skipped the phase of release, passing directly into a phase of reorganisation in 2001, followed by a phase of exploitation in 2011 (Figure 7).

Clearly, the countries of Central and Eastern Europe are massively losing their population (Figure 6) and are facing an increasingly obvious process of ageing within their populations, which involves vulnerabilities in their development. The causes are numerous and diverse, linked to political, historical and geographical particularities. The population's negative growth rate for Romania and Bulgaria (Figures 6 and 7) has two main causes: the migration towards Western Europe and the economic crisis. Two shocks that strongly destabilized the future development of the two countries, because, on the one hand, there is the massive loss of welltrained and qualified workforce, and on the other hand the economic crisis stopped or greatly reduced the investments towards residential and commercial real estate sector, their main source of economic development. There are also differences related to the overall development potential between the Western cities and the Eastern cities from Poland, Romania Bulgaria (Figures 7 and 8). Ultimately, we have countries like Hungary, the Czech Republic and Slovakia, which due to stricter socio-economic and urban policies managed to limit the extent of the negative demographic dynamic. 
Figure 6. Population growth rate vs Relative Resilience in Central and Eastern Europe

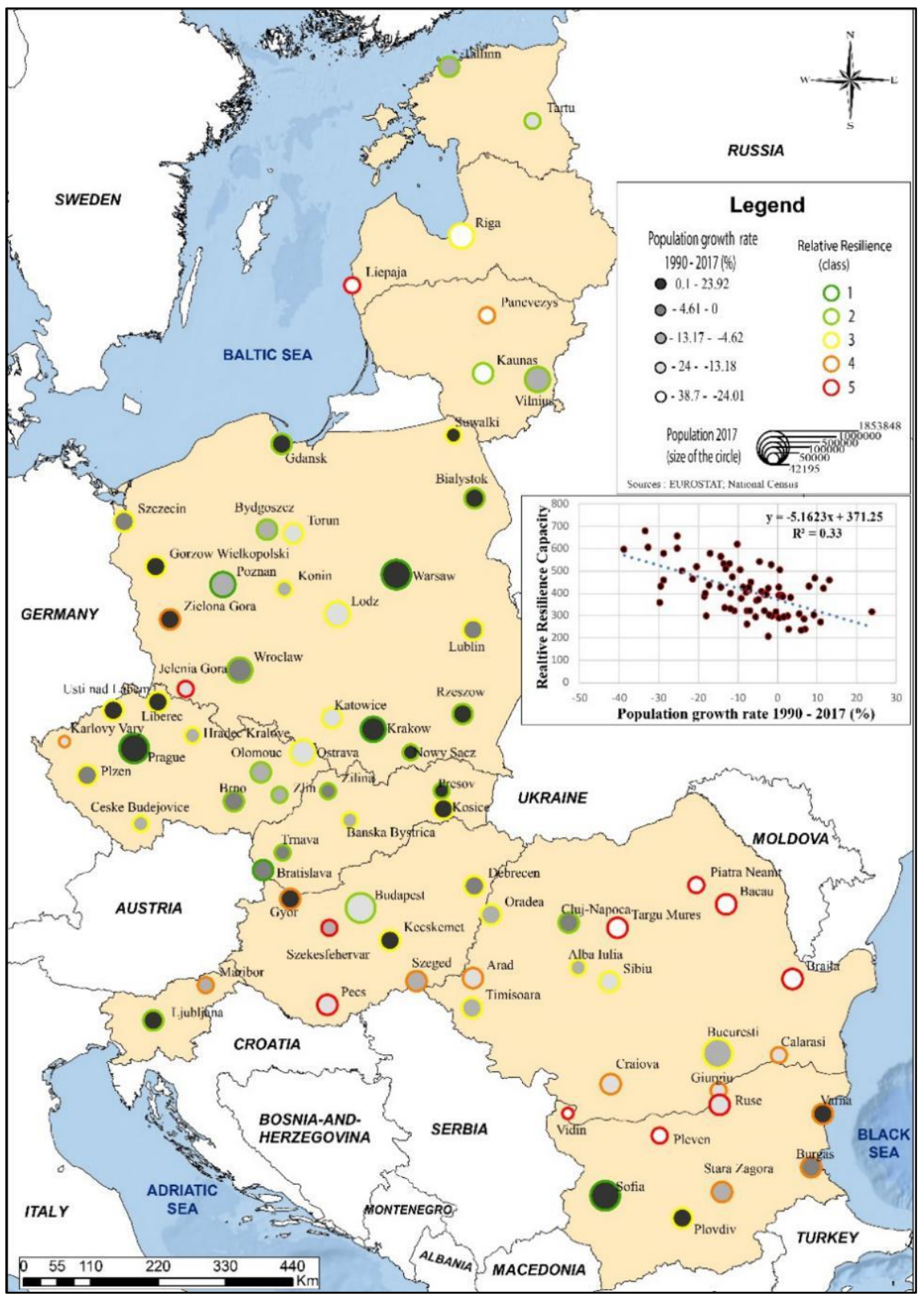

Source: Authors' representation 
Figure 7. Adaptive cycle for the demographic dynamics in Central and Eastern Europe

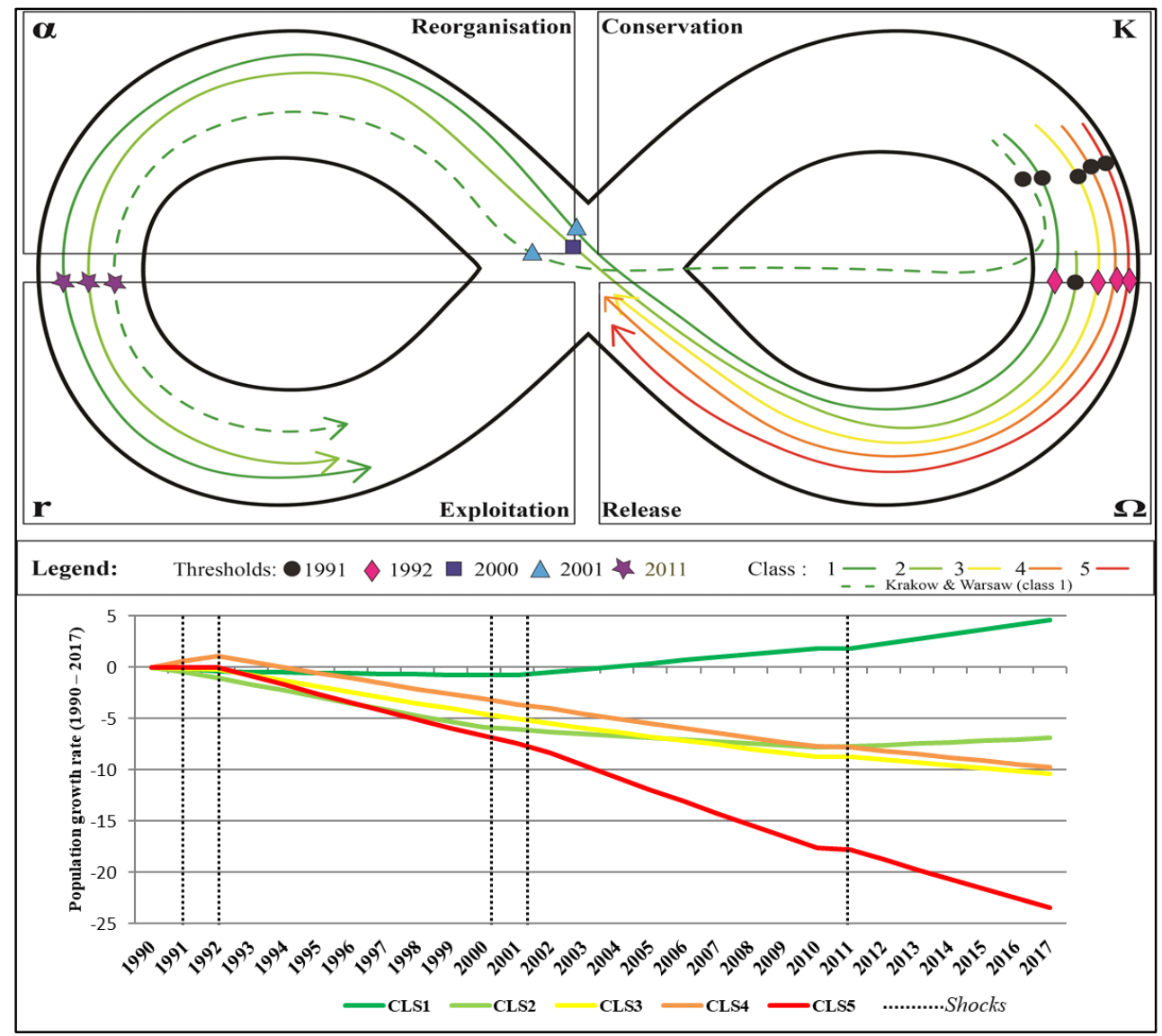

Source: Authors' representation 
Figure 8. Selected studied cities: phases of the adaptive cycle

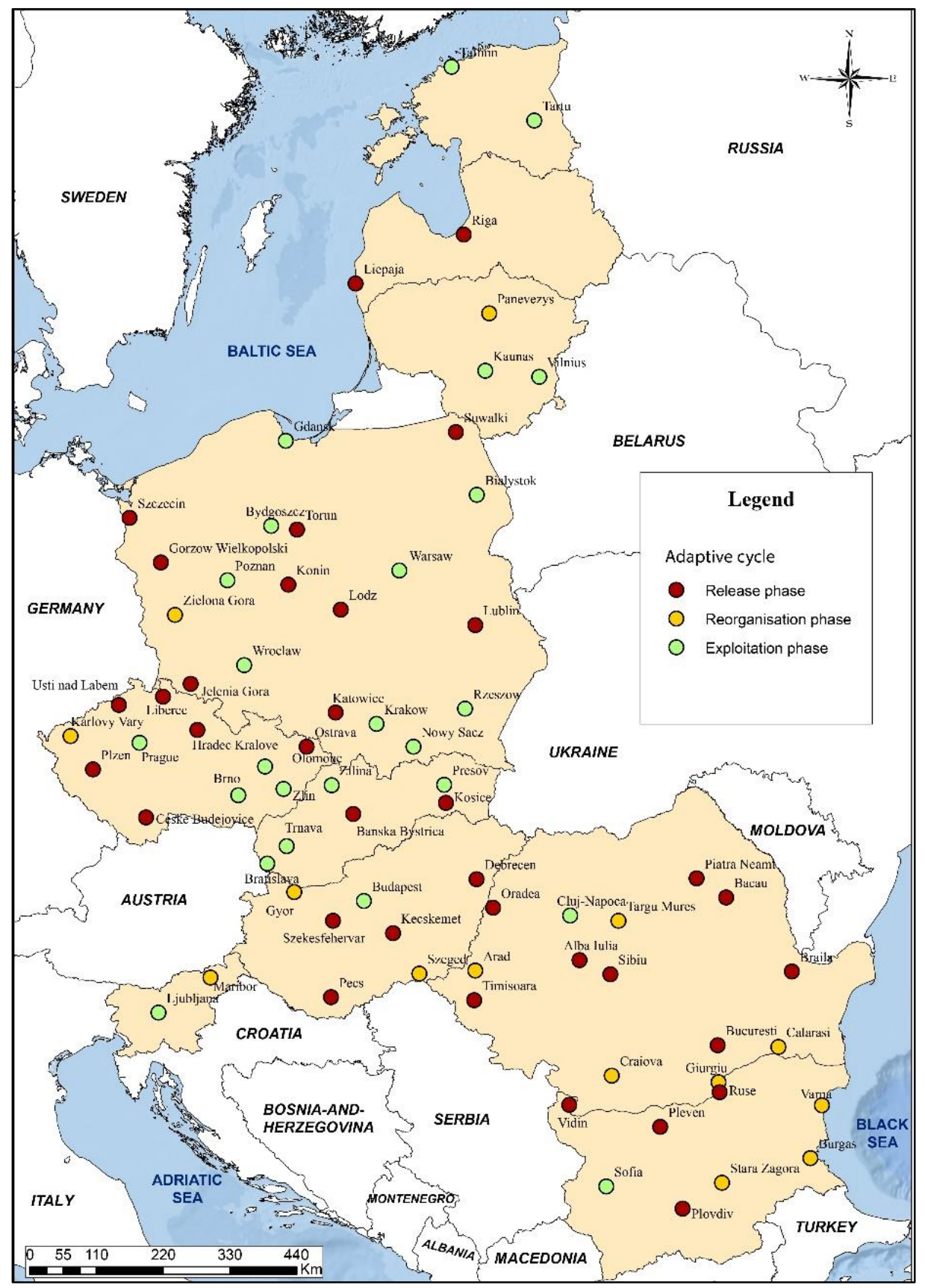

Source: Authors' representation 
Moreover, the analysis of the map above (Figure 8) shows an important heterogeneity at the national level, as well as maintaining the West-East gradient at the regional level. The cities that are in a release phase were the ones highly industrialised during the socialist period and most of them are still struggling under the weight of the socialist heritage. There are small and/or medium cities (Piatra Neamt, Ruse, Vidin, Kecskemet Jelenia Gora, Liepaja etc), that due to the failure of the former communist factories faced an exodus of the population, either to the main neighbouring cities or to the cities from Western Europe, in search of a better quality of life. However, there are also major cities (Pecs, Plovdiv, Lodz, Liberec etc.) or even capitals (Bucharest, Riga) that were not yet able to find and apply planning policies and strategies to coherently adapt to the new market order, but they have definitely more resources to do so in contrast to small cities. The reorganisation phase is characteristic to cities that focused either on the development of the tertiary sector (mainly tourism - Karlovy Vary, Varna etc.) or on investments in industrial reorganisation (Craiova, Gyor etc.)

The exploitation phase characterises the dynamic cities that have an important socio-economic weight, both within their countries and within the Central and Eastern European territory (Warsaw, Wroclaw, Prague, Bratislava, Budapest, Sofia etc.). Overall, the dynamic of the population is strongly connected with the socioeconomic and spatial development, their interdependencies being indisputable. Clearly, a city cannot evolve without high quality physical and human capital, but having a numerous population, dense constructions and infrastructure is not at all enough to ensure a resilient urban development characterised by adaptability, efficiency, connectivity, diversity etc. It is the coherent mobilisation of human, socio-economic, physical and natural elements that counts.

\section{Conclusions}

To sum up, this research aimed to capture some of the particularities of the relative resilience capacity for the selected CEE cities, highlighting their continuity or discontinuity in terms of socio-economic and spatial response to the perturbations they faced during their post-socialist urban development. However, it should be mentioned that one should take the results with a certain degree of caution, due to some limitations regarding both the availability of the data and the diversity of the data. Nonetheless, the selected indicators do cover the most frequently used ones in the international literature when analysing the urban resilience capacity.

In terms of relative resilience capacity, we have a territory of Central and Eastern Europe at several speeds, highlighted by the West-East decreasing gradient which follows the major historical axis of socio-economic development, while the Eastern countries' urban system seems to still be bound to the primacy of the capital. However, one should note the diversity of the selected cities in what concerns the relation between the resilience capacity and the growth rates for both the population 
and the built-up areas. While the latter does not show a significant correlation, there is a slightly better one with the population growth rate, a fact which opens up the possibility of using it in order to observe the resilience in terms of outcome.

Therefore, at a closer look at the population growth, one could identify relatively similar phases of transition for the last 20 years. In fact, three categories may be delineated for the adaptive path followed: cities that recovered rapidly in the 1990s, succeeding in reorganizing and growing afterwards (1); cities continuously decreasing in population size and which did not overcome the post-communist release phase (2); cities which seem to show signs of recovery and getting closer to starting the reorganisation period (3).

Finally, when analysing the land-use dynamics, one could argue that a high variety of urban functions that characterises some of the CEE cities might be a sign of resilience. Nonetheless, a reduced dynamic of the urban fabric, doubled by the presence of numerous brownfields might be a sign of resistance to change which could be associated with a "bad resilience".

In brief, cities with a better relative resilience capacity tend to perform better in what concerns the spatial urban development, as having socio-economic resources to mobilise, which also allows them to have a more coherent spatial development. Nevertheless, neither having an increased built-up area growth rate nor a low one, implies a better resilience capacity. As highlighted by our results, it is the systematic and consistent use of both socio-economic and spatial resources that makes a difference in better adapting and transforming through shocks and perturbations.

To conclude, the heterogeneity in terms of resilient response (either socioeconomic or spatial) illustrates the complexity and often the difficulties of the transition processes for the cities from Central and Eastern Europe, as well as their limited resources and/ or solutions to cope with shocks. The relative heterogeneity of the cases taken into account for both the socioeconomic and spatial dimensions can also be connected to the success rate in properly implementing regional and urban development policies and comprehensive administrative reforms capable to support good governance.

Acknowledgement: This work was supported by a grant of Ministry of Research and Innovation, CNCS - UEFISCDI, project number PN-III-P4-ID-PCCF-20160166, within PNCDI III" project ReGrowEU - Advancing ground-breaking research in regional growth and development theories, through a resilience approach: towards a convergent, balanced and sustainable European Union.

Alexandra SANDU conducted the research for this paper while working as a Teaching Associate at the Faculty of Geography and Geology, Alexandru Ioan Cuza University of Iași, Romania and as a Research Associate at UMR 5600 EVS, Lyon France. 


\section{References}

Alberti, M. and Marzluff, J.M. (2004), Ecological resilience in urban ecosystems: Linking urban patterns to human and ecological functions, Urban Ecosystems, 7(3), pp. 241265. https://doi.org/10.1023/B:UECO.0000044038.90173.c6

Allen, C.R., Gunderson, L. and Johnson, A.R. (2005), The Use of Discontinuities and Functional Groups to Assess Relative Resilience in Complex Systems, Ecosystems, 8(8), pp. 958-966.

Angeler, D.G., Allen, C.R., Rojo, C., Alvarez-Cobelas, M., Rodrigo, M.A. and SánchezCarrillo, S. (2013), Inferring the Relative Resilience of Alternative States, PLoS ONE, 8(10), p. e77338. https://doi.org/10.1371/journal.pone.0077338

ARUP (2014), City Resilience Index. Understanding and measuring city resilience, The Rockefeller Foundation, Arup (retrieved from https://www.arup.com/perspectives/ publications/research/section/city-resilience-index).

Badiu, D.L., Onose, D.A., Niţă, M.R. and Lafortezza, R. (2019), From "red” to green? A look into the evolution of green spaces in a post-socialist city, Landscape and Urban Planning, 187, pp. 156-164. https://doi.org/10.1016/j.landurbplan.2018.07.015

Bănică, A., Istrate, M., Muntele, I. (2017), Challenges for the Resilience Capacity of Romanian Shrinking Cities, Sustainability, 9(12), p. 2289. https://doi.org/10.3390/su9122289

Bănică, A. and Muntele, I. (2017), Urban transitions and resilience of Eastern European Union cities, Eastern Journal of European Studies, 8(2), pp. 45-68.

Berki, M. (2014), Return to the road of capitalism: Recapitulating the post-socialist urban transition, Hungarian Geographical Bulletin, 63(3), pp. 319-334. https://doi.org/10.15201/hungeobull.63.3.6

Bouzarovski, S., Salukvadze, J. and Gentile, M. (2011), A Socially Resilient Urban Transition? The Contested Landscapes of Apartment Building Extensions in Two Post-communist Cities, Urban Studies, 48(13), pp. 2689-2714. https://doi.org/10.1177/0042098010385158

Brand, F.S. and Jax, K. (2007), Focusing the meaning(s) of resilience: resilience as a descriptive concept and a boundary object, Ecology and Society, 12(1), pp. 23.

Briguglio, L., Cordina, G., Farrugia, N. and Vella, S. (2009), Economic Vulnerability and Resilience: Concepts and Measurements, Oxford Development Studies, 37(3), pp. 229-247. https://doi.org/10.1080/13600810903089893

Carpenter, S., Walker, B., Anderies, J.M. and Abel, N. (2001), From Metaphor to Measurement: Resilience of What to What?, Ecosystems, 4(8), pp. 765-781. https://doi.org/10.1007/s10021-001-0045-9

Carvalho, D., Martins, H., Marta-Almeida, M., Rocha, A. and Borrego, C. (2017), Urban resilience to future urban heat waves under a climate change scenario: A case study for Porto urban area (Portugal), Urban Climate, (19), pp. 1-27. https://doi.org/10.1016/j.uclim.2016.11.005 
Chelleri, L. (2012), From the «Resilient City» to Urban Resilience. A review essay on understanding and integrating the resilience perspective for urban systems, Documents d'Anàlisi Geogràfica, 58(2), pp. 287-306.

Chelleri, L., Waters, J.J., Olazabal, M. and Minucci, G. (2015), Resilience trade-offs: Addressing multiple scales and temporal aspects of urban resilience, Environment and Urbanization, 27(1), pp. 181-198. https://doi.org/10.1177/0956247814550780

Cortinovis, C., Haase, D., Zanon, B. and Geneletti, D. (2019), Is urban spatial development on the right track? Comparing strategies and trends in the European Union, Landscape and Urban Planning, 181, pp. 22-37. https://doi.org/10.1016/j.landurbplan. $\underline{2018.09 .007}$

Cutter, S. (2008), A Framework for Measuring Coastal Hazard Resilience in New Jersey Communities, White Paper for the Urban Coast Institute (retrieved from https://co.monmouth.nj.us/documents/104/CoastalHazardResilientCommunities.pdf).

da Silva, C.A., dos Santos, E.A., Maier, S.M. and da Rosa, F.S. (2019), Urban resilience and sustainable development policies: An analysis of smart cities in the state of São Paulo, Revista de Gestão, 27, pp. 61-78. https://doi.org/10.1108/REGE-12-2018-0117

Datola, G., Bottero, M. and De Angelis, E. (2019), How Urban Resilience Can Change Cities: A System Dynamics Model Approach, Computational Science and Its Applications - ICCSA 2019, Springer International Publishing, Cham, pp. 108-122.

Drobniak, A. (2017), Economic resilience and hybridization of development - A case of the Central European Regions, Regional Statistics, 7(01), pp. 43-62. https://doi.org/10.15196/RS07103

Drobniak, A. (2014), Urban resilience concept and post-industrial cities in Europe, University of Economics in Katowice, Katowice.

Ernstson, H., van der Leeuw, S.E., Redman, C.L., Meffert, D.J., Davis, G., Alfsen, C. and Elmqvist, T. (2010), Urban Transitions: On Urban Resilience and Human-Dominated Ecosystems, AMBIO, 39(8), pp. 531-545.

Foster, K.A. (2011), Resilience Capacity Index. Data, maps and findings from original quantitative research on the resilience capacity of 361 U.S. metropolitan regions.

Garcia-Ayllon, S. (2018), Urban transformations as indicators of economic change in postcommunist Eastern Europe: Territorial diagnosis through five case studies, Habitat International, 71, pp. 29-37. https://doi.org/10.1016/j.habitatint.2017.11.004

Holling, C.S. and Goldberg, M.A. (1971), Ecology and planning, Journal of the American Institute of Planners, 37(4), pp. 221-230. https://doi.org/10.1080/ $\underline{01944367108977962}$

Holling, C.S. (1986), The resilience of terrestrial ecosystems: local surprise and global change, in: Clark, W.C. and Munn, R.E. (eds.), Sustainable development of the biosphere, Cambridge: Cambridge University Press, pp. 292-317.

Hudec, O., Reggiani, A. and Šiserová, M. (2018), Resilience capacity and vulnerability: A joint analysis with reference to Slovak urban districts, Cities, 73, pp. 24-35. https://doi.org/10.1016/j.cities.2017.10.004 
Konecka-Szydłowska, B. (2018), Trajectories of the Development of Small Towns in Terms of the Urban Resilience Concept - the Demographic Dimension, Baromer Regionalny, 16(2), pp. 7-17.

Marcus, L. and Colding, J. (2014), Toward an integrated theory of spatial morphology and resilient urban systems, Ecology and Society, 19(4). http://dx.doi.org/10.5751/ES06939-190455

Martin, R. (2012), Regional economic resilience, hysteresis and recessionary shocks, Journal of Economic Geography, 12(1), pp. 1-32. https://doi.org/10.1093/jeg/lbr019

Masnavi, M.R., Gharai, F. and Hajibandeh, M. (2019), Exploring urban resilience thinking for its application in urban planning: A review of literature, International Journal of Environmental Science and Technology, 16(1), pp. 567-582. https://doi.org/10.1007/s13762-018-1860-2

Maynard, J.A., McKagan, S., Raymundo, L., Johnson, S., Ahmadia, G.N., Johnston, L., Houk, P., Williams, G.J., Kendall, M., Heron, S.F., van Hooidonk, R., Mcleod, E., Tracey, D. and Planes, S. (2015), Assessing relative resilience potential of coral reefs to inform management, Biological Conservation, 192, pp. 109-119.

Mayunga, J.S. (2007), Understanding and Applying the Concept of Community Disaster Resilience: A Capital-based Approach, Summer academy for social vulnerability and resilience building, 1(1), pp. 1-16.

Meerow, S. and Newell, J.P. (2016), Urban resilience for whom, what, when, where, and $\begin{array}{llll}\text { why?, Urban } \quad \text { Geography, } & \text { 40(3), }\end{array}$ https://doi.org/10.1080/02723638.2016.1206395

Reggiani, A., Hudec, O. and Siserova, M. (2016), Resilience capacity and vulnerability: The case of Slovakia, European Regional Science Association.

Resilience Alliance (2007), Urban resilience research prospectus (retrieved from https://issuu.com/getresilient/docs/1172764197_urbanresilienceresearchprospectusv 7 feb0).

Rizzi, P., Graziano, P. and Dallara, A. (2018), A capacity approach to territorial resilience: the case of European regions, The Annals of Regional Science, 60(2), pp. 285-328. https://doi.org/10.1007/s00168-017-0854-1

Rogov, M. and Rozenblat, C. (2018), Urban Resilience Discourse Analysis: Towards a MultiLevel Approach to Cities, Sustainability, 10(12), p. 4431. https://doi.org/10.3390/su10124431

Rufat, S. (2012), Existe-t-il une « mauvaise » résilience ?, in: La résilience urbaine. Les villes face aux catastrophes, Paris, France: Le Manuscrit, pp. 195-241.

Sandu, A. (2019), Les dynamiques urbaines post-socialistes en Europe centrale et orientale. Continuités et discontinuités dans l'évolution morphologique et fonctionnelle, $\mathrm{PhD}$ thesis, Université de Lyon (Lumière Lyon 2) et Université Al. I. Cuza de Iași.

Santos, Cruz, S., Costa, J.P.T.A., Sousa, S. and Pinho, P. (2013), Urban Resilience and Spatial Dynamics, in: Eraydin, A. and Taşan-Kok, T. (eds.), Resilience Thinking in Urban Planning, Dordrecht: Springer Netherlands, pp. 53-69. 
Sharifi, A. (2019), Resilient urban forms: A macro-scale analysis, Cities, 85, pp. 1-14. https://doi.org/10.1016/j.cities.2018.11.023

Sharifi, A. and Yamagata, Y. (2014), Major Principles and Criteria for Development of an Urban Resilience Assessment Index, in: 2014 International Conference and Utility Exhibition on Green Energy for Sustainable Development (ICUE), IEEE, Thailand.

Sharifi, A. and Yamagata, Y. (2016), Urban Resilience Assessment: Multiple Dimensions, Criteria, and Indicators, in: Yamagata, Y. and Maruyama, H. (eds.), Urban Resilience, Springer International Publishing, Cham, pp. 259-276.

Stanilov, K. (2007), The post-socialist city: urban form and space transformations in Central and Eastern Europe after socialism, Dordrecht: Springer. https://doi.org/10.1007/978-1-4020-6053-3

Sykora, L. and Bouzarovski, S. (2012), Multiple Transformations: Conceptualising the Postcommunist Urban Transition, Urban Studies, 49(1), pp. 43-60. https://doi.org/10.1177/0042098010397402

Tsenkova, S. and Budic, Z.N. (2006), The urban mosaic of post-socialist Europe: space, institutions and policy, Heidelberg: Physica-Verl. https://doi.org/10.1007/3-7908$\underline{1727-9}$ 